\title{
Pengembangan Perangkat Pembelajaran Matematika Berbasis Problem Based Learning untuk Siswa Kelas VII Semester 1 SMP/MTs Materi Bilangan dan Himpunan
}

\author{
${ }^{1}$ Armis \\ ${ }^{2}$ Suhermi \\ 1,2 Program Studi Pendidikan Matematika FKIP Universitas Riau \\ Kampus Bina Widya KM 12,5 Simpang Baru, Pekanbaru 28293, Indonesia \\ E-mail:1armis t@yahoo.com
}

\begin{abstract}
This study aims to develop the learning of mathematics 1st junior class VII, on Numbers and Set. The learning tools developed consists of a syllabus, Lesson Plan (RPP), Sheet Teaching Materials (LMA), Student Activity Sheet (LAS), instructional media, and Authentic Assessment Sheet (LPA). This study is the research, development model 4-D which consists of four stages: Define, Design, Develop, and Disseminate. In this study the development process undertaken only to phase 3. The learning tools that have been developed, validated by two-person of experts and two practitioners then conducted a limited trial to the junior high school students in coastal areas. Data validation and students' responses collected through questionnaires which are then revised on the advice. From the results of the validation data showed the average score was 3.93 for syllabus (very valid), RPP was 3.44 (very valid), LAS was 3,67 (very valid), LMA was 3.83 (very valid), LMP was 3.92 (very valid), and the average score of the students' response was 3.76 (very practical). From the development of learning tools that have been carried out it is concluded that a learning tool developed very valid and ready to be tested on students of SMP / MTs by a larger amount.
\end{abstract}

Keywords: Learning Tools, Problem Based Learning, Numbers and Set.

\begin{abstract}
Abstrak
Penelitian ini bertujuan mengembangkan perangkat pembelajaran matematika SMP kelas VII pada materi Bilangan dan Himpunan. Perangkat pembelajaran yang dikembangkan terdiri dari Silabus, Rencana Pelaksanaan Pembelajaran (RPP), Lembar Materi Ajar (LMA), Lembar Aktifitas Siswa (LAS), media pembelajaran, dan Lembar Penilaian Autentik (LPA). Penelitian ini merupakan penelitian pengembangan model 4-D yang terdiri dari 4 tahap yaitu pendefenisian (define), perancangan (design), pengembangan (develop), dan penyebaran (disseminate). Proses pengembangan dilakukan hanya sampai tahap ke-3. Perangkat yang dikembangkan, divalidasi oleh dua orang tim ahli dan dua orang praktisi pendidikan kemudian dilakukan ujicoba terbatas. Data validasi dan respon siswa dikumpulkan melalui angket yang direvisi sesuai saran. Dari hasil validasi diperoleh data rata-rata skor silabus adalah 3,93 (sangat valid), rata-rata skor RPP adalah 3,44 (sangat valid), rata-rata skor LAS adalah 3,67 (sangat valid), rata-rata skor LMA adalah 3,83 (sangat valid), rata-rata skor LMP adalah 3,92 (sangat valid), rata-rata skor respon siswa adalah 3,76 (sangat praktis), Hasil Penelitian diperoleh bahwa perangkat yang dikembangkan sangat valid dan siap untuk diujicobakan kepada siswa SMP/MTs dengan jumlah yang lebih besar.
\end{abstract}

Kata Kunci: Perangkat Pembelajaran, Problem Based Learning, Bilangan dan Himpunan. 


\section{Pendahuluan}

Matematika adalah ilmu yang keberadaannya sangat diperlukan oleh ilmu-ilmu lain. Oleh sebab itu matematika perlu diajarkan di semua jenjang pendidikan. Matematika yang diajarkan di jenjang Pendidikan Dasar dan Pendidikan Menengah disebut Matematika Sekolah, yaitu bagian dari materi matematika yang dipilih sesuai dengan tingkat berpikir siswa di jenjang pendidikan tertentu. Agar matematika sekolah dapat dikuasai dengan baik oleh siswa diperlukan pembelajaran yang berkualitas. Akhsanul In'am mengemukakan bahwa pembelajaran matematika sudah seharusnya dirancang untuk membantu siswa memahami materi yang sedang dipelajari dengan mudah, sehingga peran guru dan siswa dalam pembelajaran matematika di kelas perlu diperhatikan. Oleh karena itu, aktifitas yang dilaksanakan guru pada kegiatan pembelajaran, baik merancang pelaksanaan pembelajaran, melaksanakan rancangan maupun melakukan evaluasi adalah sangat berpengaruh terhadap pencapaian prestasi siswa.

Sebagai tenaga yang profesional, guru harus mempersiapkan diri secara maksimal sebelum melaksanakan pembelajaran di kelas. Persiapan tersebut dituangkan dalam bentuk perangkat pembelajaran. Trianto mengemukakan bahwa perangkat pembelajaran adalah suatu perangkat yang digunakan untuk mengelola proses pembelajaran ${ }^{1}$. Sedangkan Nazarudin menyatakan bahwa perangkat pembelajaran adalah suatu atau beberapa persiapan yang disusun oleh guru baik selaku individu maupun kelompok agar pelaksanaan dan evaluasi pembelajaran dapat dilakukan secara sistematis dan memperoleh hasil seperti yang diharapkan ${ }^{2}$. Perangkat pembelajaran tersebut dapat berupa silabus, rencana pelaksanaan pembelajaran (RPP), lembar kegiatan siswa (LKS), instrumen penilaian, media pembelajaran dan lain sebagainya.

Dari dua pendapat tersebut disimpulkan bahwa perangkat pembelajaran adalah komponen pembelajaran yang harus disiapkan guru sebagai penyelenggara pembelajaran sehingga pembelajaran yang dilakukan dapat berjalan efektif, efisien dan memperoleh hasil yang diharapkan. Perangkat pembelajaran yang optimal terdiri atas (1) silabus, (2) Rencana Pelaksanaan Pembelajaran (RPP), (3) Lembar Materi Ajar (LMA), (4) Lembar Aktifitas Siswa (LAS), (5) media pembelajaran, dan (6) lembar penilaian autentik.

1 Trianto, Mendesain Model Pembelajaran Inovatif-Progresif (Jakarta: Kencana Prenada Media Group, 2009).

${ }^{2}$ Nazaruddin, Manajemen Pembelajaran (Yogyakarta: Teras, 2007). 
Depdiknas menyatakan bahwa pengembangan perangkat pembelajaran penting dengan alasan antara lain ketersediaan bahan sesuai tuntutan kurikulum, karakteristik sasaran, dan tuntutan pemecahan masalah belajar ${ }^{3}$. Perangkat pembelajaran yang akan dikembangkan harus sesuai dengan tuntutan kurikulum. Apabila perangkat pembelajaran yang sesuai dengan tuntutan kurikulum tidak tersedia atau sulit diperoleh, maka membuat perangkat pembelajaran sendiri adalah suatu keputusan yang bijak. Selanjutnya, pengembangan perangkat pembelajaran harus dapat memecahkan masalah kesulitan belajar yang dapat terjadi karena materi tersebut abstrak, rumit, asing, dan lain sebagainya.

Tak dapat dipungkiri bahwa masih banyak guru yang tidak memiliki perangkat pembelajaran sehingga tampil di kelas tanpa persiapan, bahkan lebih memprihatinkan lagi guru mempunyai perangkat pembelajaran yang telah turun temurun dari guru-guru sebelumnya dan digunakan sebagai formalitas administrasi saja tanpa tahu isi dan kegunaaannya. Berdasarkan hasil wawancara peneliti terhadap beberapa orang guru matematika SMP/MTs di Kabupaten Rokan Hilir diperoleh informasi bahwa dalam proses pembelajaran guru jarang bahkan tidak mengembangkan perangkat pembelajaran untuk mencapai tujuan pembelajaran yang diinginkan, dimana perangkat pembelajaran yang digunakan selama ini hanya menggunakan perangkat pembelajaran berupa RPP, silabus, buku pegangan. RPP yang digunakan selama ini tidak menggunakan langkah-langkah pembelajaran yang ada, dan buku pegangan guru sama dengan buku pegangan siswa yang dibeli di toko-toko buku yang tersedia, serta permasalahan-permasalahan yang ada pada buku tidak mengarah pada dunia nyata siswa. Pada sekolah yang telah melaksanakan kurikulum 2013 telah disediakan buku guru dan buku siswa, namun untuk melaksanakan kurikulum 2013 tersebut guru harus terampil menerapkan model pembelajaran yang sesuai dengan materi yang akan diajarkan. Karena pada umumnya guru belum memahami modelmodel pembelajaran inovatif maka guru mengalami kesulitan untuk merancang perangkat pembelajaran yang akan dilaksanakan dalam pembelajaran dan menentukan alat evaluasi hasil belajar.

Aplikasi kurikulum mempunyai aplikasi pendekatan pembelajaran berbeda-beda, demikian juga halnya pada kurikulum 2013. Secara umum pelaksanaan pembelajaran dalam kurikulum 2013 menggunakan pendekatan saintifik. Dalam pendekatan saintifik, guru melakukan langkah-langkah pembelajaran sesuai dengan pendekatan ilmiah. Pendekatan saintifik dalam pembelajaran matematika dapat didefinisikan sebagai pembelajaran yang dirancang sedemikian rupa sehingga siswa secara aktif mengonstruksi

\footnotetext{
${ }^{3}$ Depdiknas, Panduan Pengembangan Bahan Ajar (Jakarta: Depdiknas, 2008).
} 
konsep, hukum dan prinsip melalui tahapan-tahapan mengamati, menanya, menalar, mencoba, dan menarik kesimpulan. Pendekatan saintifik dimaksudkan untuk memberikan pemahaman kepada siswa dalam mengenal dan mempelajari berbagai materi menggunakan pendekatan ilmiah. Informasi dapat berasal dari mana saja, kapan saja, tidak bergantung pada informasi searah dari guru. Oleh karena itu kondisi pembelajaran yang diharapkan dapat mendorong siswa mencari tahu dari berbagai sumber.

Salah satu model pembelajaran dalam kurikulum 2013 yang sejalan dengan pendekatan saintifik adalah model Pembelajaran Berdasakan Masalah atau dikenal dengan Problem Based Learning (PBL). PBL adalah suatu model pembelajaran yang berawal dari permasalahan yang akan dipecahkan. Dengan menggunakan model ini, materi disajikan berdasarkan masalah yang dekat dengan siswa dan menuntut siswa menggunakan pengalamannya untuk menyelesaikan permasalahan tersebut. Model pembelajaran berbasis masalah dilakukan dengan adanya pemberian rangsangan berupa masalah-masalah yang kemudian dilakukan pemecahan masalah oleh siswa yang diharapkan dapat menambah keterampilan siswa dalam pencapaian materi pembelajaran.

Berdasarkan fakta tersebut, maka peneliti tertarik untuk mengembangkan perangkat pembelajaran lengkap yang optimal terdiri atas (1) silabus, (2) Rencana Pelaksanaan Pembelajaran (RPP), (3) Lembar Materi Ajar (LMA), (4) Lembar Aktifitas Siswa (LAS), (5) media pembelajaran, dan (6) lembar penilaian autentik, yang nantinya dapat disumbangkan ke SMP/MTs di daerah pesisir yang ada di provinsi Riau

\section{Kerangka Teoretis}

\section{Perangkat Pembelajaran}

Erman Suherman mengemukakan bahwa pembelajaran merupakan proses komunikasi antara siswa dengan guru dan siswa dengan siswa yang bertujuan agar terjadi perubahan sikap dan pola pikir yang akan menjadi kebiasaan bagi siswa yang bersangkutan ${ }^{4}$. Lebih lanjut, Trianto menyatakan bahwa pembelajaran merupakan interaksi dua arah dari seorang guru dan siswa, dimana antara keduanya terjadi komunikasi (transfer) yang intens dan terarah menuju pada suatu target yang telah ditetapkan sebelumnya ${ }^{5}$. Dari dua pengertian pembelajaran tersebut disimpulkan bahwa pembelajaran merupakan suatu interaksi siswa dengan guru, siswa dengan siswa, dan sumber belajar lainnya sehingga terjadi perubahan pola pikir dan

\footnotetext{
${ }^{4}$ Suherman, Strategi Pembelajaran Matematika Kontemporer (Surabaya: JICA, 2001).

${ }_{5}^{5}$ Trianto, Mendesain Model Pembelajaran Inovatif-Progresif.
} 
tingkah laku yang menyebabkan siswa dapat melakukan proses belajar dengan mudah sehingga dapat mencapai target tertentu

Trianto mengemukakan bahwa perangkat pembelajaran adalah suatu perangkat yang digunakan untuk mengelola proses pembelajaran ${ }^{6}$. Lebihlanjut Nazarudin menyatakan bahwa perangkat pembelajaran adalah suatu atau beberapa persiapan yang disusun oleh guru baik selaku individu maupun kelompok agar pelaksanaan dan evaluasi pembelajaran dapat dilakukan secara sistematis dan memperoleh hasil seperti yang diharapkan7. Dari dua pendapat tersebut disimpulkan bahwa perangkat pembelajaran adalah persiapan pembelajaran yang harus disiapkan oleh guru sebagai penyelenggara pembelajaran sehingga pembelajaran yang dilakukan dapat berjalan efektif, efisien dan memperoleh hasil yang diharapkan. Perangkat pembelajaran tersebut dapat berupa silabus, rencana pelaksanaan pembelajaran (RPP), lembar aktifitas siswa (LAS), instrumen penilaian, media pembelajaran dan lain sebagainya.

Dalam Permendikbud Nomor 58 tahun 2014 dijelaskan bahwa silabus digunakan oleh guru sebagai acuan dalam penyusunan rencana pelaksanaan pembelajaran. Silabus berisikan Kompetensi Inti, Kompetensi Dasar, materi pembelajaran, kegiatan pembelajaran, penilaian, alokasi waktu, dan sumber belajar. Berdasarkan Permendikbud Nomor 103 Tahun 2014, RPP merupakan rencana pembelajaran yang dikembangkan secara rinci mengacu pada silabus. Berikutnya juga dijelaskan bahwa RPP minimal harus memuat (1) identitas sekolah, mata pelajaran, kelas/semester, dan alokasi waktu; (2) Kompetensi Inti, Kompetensi dasar, dan indikator pencapaian kompetensi; (3) materi pembelajaran; (4) kegiatan pembelajaran yang meliputi kegiatan pendahuluan, kegiatan inti dan kegiatan penutup; (5) penilaian, pembelajaran remedial,dan pengayaan; dan (6) media, alat, bahan, dan sumber belajar.

Menurut Andi Prastowo, LAS merupakan bahan ajar cetak berupa lembaran-lembaran kertas yang berisi materi, ringkasan dan petunjukpetunjuk pelaksanaan tugas pembelajaran yang harus dilakukan oleh siswa, yang mengacu pada kompetensi dasar yang harus dicapai ${ }^{8}$. Setiap pendidik dalam menyediakan LKS harus memperhatikan beberapa persyaratan penyusunan LKS sehingga kompetensi dasar yang harus dikuasai oleh siswa dapat tercapai. Oleh karena itu, pendidik akan dapat menyusun LKS yang baik apabila memiliki keterampilan yang cukup. Struktur LKS secara umum

${ }^{6}$ Ibid.

${ }^{7}$ Nazaruddin, Manajemen Pembelajaran.

8 Andi Prastowo, Panduan Kreatif Membuat Bahan Ajar Inovatif (Yogyakarta: Duva Press, 2011).

Al-Khwarizmi - 29 
yaitu: (1) judul, mata pelajaran, semester, tempat; (2) petunjuk belajar; (3) kompetensi yang akan dicapai; (4) indikator; (5) informasi pendukung; (6) tugas-tugas dan langkah-langkah kerja; dan (7) penilaian 9.

Berdasarkan permendikbud no 23 tahun 2016 penilaian yang digunakan meliputi sikap, pengetahuan, dan ketrampilan. Penilaian harus bersifat sahih, objektif, dan adil. Kunandar mengemukakan bahwa salah satu penekanan dalam kurikulum 2013 adalah penilaian autentik (authentic assessment), karena penilaian semacam ini mampu menggambarkan peningkatan hasil belajar siswa, baik dalam rangka mengobservasi, menalar, mencoba, membangun jejaring, dan lain-lain 10. Penilaian autentik adalah kegiatan menilai siswa yang menekankan pada apa yang seharusnya dinilai, baik proses maupun hasil dengan berbagai istrumen penilaian yang disesuaikan dengan tuntutan kompetensi yang ada di kompetensi inti dan kompetensi dasar.

\section{Model Pembelajaran Problem Based Learning}

Problem Based Learning merupakan salah satu model pembelajaran yang dapat membantu siswa untuk meningkatkan keterampilan yang dibutuhkan pada era globalisasi saat ini. PBL dikembangkan pertama kali oleh Prof. Howard Barrows sekitar tahun 1970-an dalam pembelajaran ilmu medis di McMaster University Canada ${ }^{11}$. Model pembelajaran ini menyajikan suatu masalah yang nyata bagi siswa sebagai awal pembelajaran kemudian diselesaikan melalui penyelidikan dan diterapkan dengan menggunakan pemecahan masalah.

Trianto menyatakan ciri utama model PBL, yaitu12 :

1. Pengajuan pertanyaan atau masalah.

Peran guru dalam menyajikan fenomena yang berkaitan dengan permasalahan matematika dalam kehidupan nyata sangat penting untuk memunculkan pertanyaan-pertanyaan atau permasalahan dalam diri siswa.

${ }^{9}$ Aris Dwicahyono, Pengembangan Perangkat Pembelajaran (Yogyakarta: Gava Media, 2014).

10 Kunandar, Penilaian Autentik (Penilaian Hasil Belajar Peserta Didik Berdasarkan Kurikum 2013) (Jakarta: PT Raja Grafindo Persada, 2014).

11 Muhammad Taufiq Amir, Inovasi Pendidikan Melalui Problem Based Learning: Bagaimana Pendidik Memberdayakan Pebelajar Di Era Pengetahuan (Jakarta: Kencana Prenada Media Group, 2009).

12 Trianto, Model-Model Pembelajaran Inovatif Berorientasi Konstruktivis (Jakarta: Prestasi Pustaka Publisher, 2007). 
2. Berfokus pada keterkaitan antar disiplin.

Dalam penyelesaian permasalahan matematika dalam kehidupan, siswa perlu meninjau kaitan permasalahan dengan mata pelajaran.

3. Penyelidikan autentik.

Pada model pembelajaran ini siswa dituntut untuk melakukan penyelidikan guna memecahkan permasalahan.

4. Menghasilkan produk atau karya.

Pembelajaran ini juga menuntut siswa untuk menghasilkan suatu karya, misalkan berupa laporan yang mewakili bentuk penyelesaian masalah yang mereka temukan.

5. Kolaborasi.

Pembelajaran ini memudahkan siswa yang bekerja dalam kelompok kecil untuk menyelesaikan masalah bersam-sama dengan teman satu kelompok. Dengan adanya kelompok diharapkan siswa dapat saling bertukar pikiran dan pendapat dalam melakukan penyelidikan sehingga dapat dengan mudah menyelesaikan masalah yang disajikan.

Problem based learning terdiri atas lima fase pembelajaran seperti disajikan dalam Tabel 1 berikut.

Tabel 1. Fase Model Pembelajaran Berbasis Masalah

\begin{tabular}{|l|l|}
\hline \multicolumn{1}{|c|}{ Fase } & \multicolumn{3}{|c|}{ Perilaku Guru } \\
\hline $\begin{array}{l}\text { Fase 1 } \\
\text { masalah }\end{array}$ & $\begin{array}{l}\text { Menjelaskan pembelajaran, } \\
\text { menjelaskan logistik yg dibutuhkan. } \\
\text { Memotivasi siswa untuk terlibat aktif dalam } \\
\text { pemecahan masalah yang dipilih. }\end{array}$ \\
\hline $\begin{array}{l}\text { Fase 2 } \\
\text { Mengorganisasi siswa }\end{array}$ & $\begin{array}{l}\text { Membantu siswa mendefinisikan dan } \\
\text { mengorganisasikan tugas belajar yang } \\
\text { berhubungan dengan masalah tersebut. }\end{array}$ \\
\hline $\begin{array}{l}\text { Fase 3 } \\
\text { Membimbing } \\
\text { penyelidikan individu } \\
\text { dan kelompok }\end{array}$ & $\begin{array}{l}\text { Mengumpulkan informasi yang sesuai, } \\
\text { melaksanakan eksperimen untuk } \\
\text { mendapatkan penjelasan dan pemecahan } \\
\text { masalah. }\end{array}$ \\
\hline $\begin{array}{l}\text { Fase 4 } \\
\text { Mengembangkan dan } \\
\text { menyajikan hasil karya }\end{array}$ & $\begin{array}{l}\text { Membantu siswa dalam merencana dan } \\
\text { menyiapkan karya yang sesuai seperti } \\
\text { laporan, model dan berbagi tugas dengan } \\
\text { teman. }\end{array}$ \\
\hline $\begin{array}{l}\text { Fase 5 } \\
\text { Menganalisa dan } \\
\text { mengevaluasi proses } \\
\text { pemecahan masalah }\end{array}$ & $\begin{array}{l}\text { Mengevaluasi hasil belajar tentang materi } \\
\text { mempresen tasikan hasil kerja }\end{array}$ \\
\hline
\end{tabular}

Sumber: Rusman ${ }^{13}$

13 Rusman, Model-Model Pembelajaran Mengembangkan Profesionalisme Guru (Jakarta: Rajawali Press, 2012).

Al-Khwarizmi - 31 
Dari uraian tersebut dapat diketahui bahwa pembelajaran berbasis masalah menekankan pada proses mencari atau mengkonstruksi pengetahuan secara mandiri. Siswa secara aktif terlibat dalam pembelajaran yang dilakukan sehingga kebermaknaan belajar dapat tercipta. Oleh karena itu, guru harus mampu menciptakan situasi belajar yang dapat melibatkan siswa secara aktif untuk berperan dalam pembelajaran yang dilakukan. Dari situasi ini, pembelajaran berbasis masalah adalah suatu model pembelajaran yang berpusat pada siswa, bukan pada guru.

\section{Pendekatan Saintifik}

Kurikulum 2013 menekankan pembelajaran pada pendekatan saintifik dimana pembelajarannya berpusat pada siswa. Secara garis besar pendekatan saintifik harus (a) melibatkan keterampilan proses sains dalam mengontruksi konsep, hukum atau prinsip, (b) melibatkan proses-proses kognitif yang potensial dalam merangsang perkembangan intelek, khususnya keterampilan berpikir tingkat tinggi siswa, (c) dapat mengembangkan karakter siswa. Pendekatan ilmiah merupakan pembelajaran yang mengadopsi langkah-langkah saintis dalam membangun pengetahuan melalui metode ilmiah. Dalam pendekatan saintifik, guru melakukan langkah-langkah pembelajaran sesuai dengan pendekatan ilmiah. Pendekatan saintifik dalam pembelajaran matematika dapat didefinisikan sebagai pembelajaran yang dirancang sedemikian rupa sehingga siswa secara aktif mengonstruksi konsep, hukum dan prinsip melalui tahapan-tahapan mengamati, menanya, menalar, mencoba dan mengomunikasikan.

\section{Pengujian Validitas dan Praktikalitas Perangkat Pembelajaran}

Menurut Azhar Arsyad, validitas berasal dari kata validity yang mempunyai arti sejauh mana ketepatan dan kecermatan suatu alat ukur dalam melakukan fungsi ukurnya ${ }^{14}$. Sementara Anas Sudijono menyatakan bahwa validitas adalah suatu ukuran yang menunjukkan tingkat kesahihan suatu tes ${ }^{15}$. Lebih lanjut, menurut Sugiyono validasi diartikan sebagai suatu tindakan yang membuktikan bahwa suatu proses/metode dapat memberikan hasil yang konsisten sesuai dengan spesifikasi yang telah ditetapkan dan terdokumentasi dengan baik ${ }^{16}$.

${ }^{14}$ Azhar Arsyad, Media Pembelajaran (Jakarta: Raja Grafindo Persada, 2007).

${ }^{15}$ Anas Sudjono, Pengantar Statistik Pendidikan (Jakarta: Rajawali Press, 2009).

16 Sugiyono, Metode Penelitian Pendidikan Pendekatan Kuantitatif, Kualitatif, Dan R \& $D$ (Bandung: Alfabeta, 2013). 
Berdasarkan beberapa pendapat tersebut, dalam kaitannya dengan perangkat pembelajaran, peneliti menyimpulkan validitas adalah tingkat kevalidan atau kesahihan suatu perangkat pembelajaran. Untuk memperoleh validitas tersebut perlu dilakukan pengujian yang disebut uji validitas atau validasi.

Terdapat 3 cara pengujian validitas yaitu ${ }^{17}$ :

1. Pengujian validitas konstruksi, pengujian ini dilakukan dengan menggunakan pendapat para ahli (judgement expert)

2. Pengujian validitas isi, pengujian ini dilakukan dengan membandingkan isi instrumen dengan materi pelajaran yang akan diajarkan

3. Pengujian validitas eksternal, pengujian ini dilakukan dengan cara membandingkan antara kriteria yang ada pada instrumen dengan faktafakta empiris yang terjadi di lapangan.

Setelah perangkat pembelajaran divalidasi perlu diuji praktikalitasnya. Menurut kamus besar Bahasa Indonesia, praktikalitas berarti bersifat praktis, artinya mudah dan senang memakainya ${ }^{18}$. Suatu produk, dalam hal ini perangkat pembelajaran dikatakan praktis jika perangkat tersebut dapat digunakan. Sugiyono mengartikan bahwa praktikalitas perangkat pembelajaran adalah perangkat pembelajarn yang dihasilkan dapat dimengerti oleh siswa ${ }^{19}$.

Menurut Ishaq Madeamin, pertimbangan praktikalitas dapat dilihat dalam aspek berikut ${ }^{20}$ :

1. Kemudahan penggunaan, meliputi mudah diatur, disimpan, dan dapat digunakan sewaktu-waktu.

2. Waktu yang diperlukan dalam pelaksanaan singkat, cepat dan tepat.

3. Mudah diinterpretasikan oleh dosen ahli maupun dosen lain.

4. Biaya murah dan dapat dijangkau oleh siswa maupun berbagai pihak yang hendak menggunakannya.

17 Ibid.

18 Eko Putro Widoyoko, Kamus Besar Bahasa Indonesia, 4th ed. (Jakarta: PT. Gramedia Pustaka Utama, 2008).

${ }^{19}$ Sugiyono, Metode Penelitian Pendidikan Pendekatan Kuantitatif, Kualitatif, Dan R \& D.

20 Ishaq Madeamin, 'Objektivitas Dan Kepraktisan', 2011, http://shahibul1628.wordpress.com/2012/04/12/kepraktisan-dan-efek-potensial/.

Al-Khwarizmi - 33 


\section{Metode Penelitian}

Penelitian iniberbentuk penelitian pengembangan model 4-D. Trianto mengemukakan bahwa empat tahap dari model penelitian pengembangan meliputi pendefenisian (define), perancangan (design), pengembangan (develop), dan penyebaran (disseminate). Tahap pendefenisian (define) adalah menetapkan dan mendefenisikan syarat-syarat pembelajaran. Tahap perencanaan (design) adalah untuk menyiapkan prototype media pembelajaran. Tahap pengembangan (develop) adalah untuk menghasilkan media pembelajaran yang sudah direvisi berdasarkan masukan dari para pakar. Tahap penyebaran (disseminate) adalah tahap penggunaan media pada skala yang lebih luas 21 .

Untuk mengumpulkan data yang diperlukan digunakan teknik sebagai berikut.

1. Teknik kepustakaan untuk mengembangkan perangkat pembelajaran

2. Teknik angket untuk mengumpulkan data kevalidan perangkat pembelajaran yang diedarkan kepada dua orang tim ahli dan dua orang praktisi pendidikan dengan menggunakan skor 1, 2, 3, 4

3. Teknik angket untuk mengumpulkan data kepraktisan LAS yang diedarkan kepada siswa dengan menggunakan skor 1, 2, 3, 4

4. Teknik ujicoba terbatas untuk mengumpulkan data kelayakan perangkat untuk siswa di daerah pesisir.

Angket tentang kevalidan RPP memuat enam komponen utama yang terdiri atas (1) identitas RPP; (2) rumusan indikator pencapaian kompetensi dan tujuan pembelajaran; (3) pemilihan materi pembelajaran; (4) perumusan kegiatan pembelajaran menggunakan model PBL dengan pendekatan saintifik; (5) pemilihan sumber belajar; dan (6) penilaian hasil belajar. Angket tentang kevalidan LAS memuat lima komponen utama yang terdiri atas (1) kualitas materi LAS; (2) kesesuaian LAS dengan model PBL dan pendekatan saintifik; (3) Kesesuaian Las dengan syarat didaktik; (4) kesesuaian LAS dengan syarat konstruksi pengetahuan; (5) kesesuaian LAS dengan syarat teknis penyususnan LAS. Selanjutnya angket tentang kepraktisan LAS yang diedarkan kepada siswa memuat lima komponen utama yang terdiri atas (1) materi; (2) tampilan; (3) kemudahan penggunaan LAS; (4) permasalahan berbasis kontekstual; (5) sikap yang dapat ditumbuhkan oleh penggunaan LAS.

21 Trianto, Model-Model Pembelajaran Inovatif Berorientasi Konstruktivis. 
Adapun kriteria angket respon tim ahli dan praktisi terhadap kevalidan perangkat pembelajaran serta respon siswa terhadap kepraktisan LAS yang digunakan dapat dilihat pada Tabel 2 berikut :

Tabel 2. Kategori Kevalidan Perangkat Pembelajaran, dan Kepraktisan LAS

\begin{tabular}{|c|c|}
\hline Interval & Kategori \\
\hline $3,00 \leq \bar{x} \leq 4$ & Sangat Valid / Sangat Praktis \\
\hline $2,00 \leq \bar{x}<3,00$ & Valid / Praktis \\
\hline $1,00 \leq \bar{x}<2,00$ & Kurang Valid / Kurang Praktis \\
\hline
\end{tabular}

Sumber: Modifikasi dari Arikunto.

Berdasarkan komentar dan saran dari validator, praktisi, dan respon siswa dapat disimpulkan kelayakan perangkat pembelajaran sebagai berikut.

1. Layak diujicobakan tanpa revisi

2. Layak diujicobakan dengan revisi sesuai saran validator

3. Belum layak diujicobakan

\section{Hasil Rekomendasi Tim Ahli}

Produk penelitian ini berupa perangkat pembelajaran yang terdiri atas (1) silabus, (2) Rencana Pelaksanaan Pembelajaran (RPP), (3) Lembar Materi Ajar (LMA), (4) Lembar Aktifitas Siswa (LAS), (5) media pembelajaran, dan (6) Lembar Penilaian Autentik (LPA). Hasil rekomendasi dari tim ahli dan praktisi pendidikan terhadap perangkat pembelajaran serta respon siswa terhadap Lembar Aktifitas Siswa disajikan dalam tabel 3 sampai dengan tabel 8 berikut.

Komponen penilaian terhadap perangkat pembelajaran yang dimaksud terdiri dari:

1. Silabus: Perumusan kompetensi dasar, kelengkapan materi pembelajaran, Kebenaran Indikator Pencapaian Kompetensi, Ketepatan Kegiatan Pembelajaran, Kelengkapan Penilaian Autentik, Penetapan Alokasi Waktu, dan Pemilihan Sumber Belajar.

2. Lembar Materi Aljabar: Kesesuaian materi dengan IPK., Kesesuaian materi dengan konsep, Kedalaman materi pembelajaran., Keluasan materi pembelajaran., Kekontekstualan contoh., dan Ketepatan istilah/simbol..

3. Rencana Pelaksanaan Pembelajaran: Identitas RPP, Kesesuaian Rumusan IPK dan tujuan pembelajaran, Pemilihan materi pembelajaran, Perumusan kegiatan pembelajaran menggunakan model PBL dengan pendekatan saintifik, Pemilihan sumber belajar, dan Penilaian hasil belajar. 
4. Lembar Aktifitas Siswa: Kualitas materi LAS, Kesesuaian LAS dengan model PBL dan pendekatan saintifik, Kesesuaian Las dengan syarat didaktik, Kesesuaian LAS dengan syarat konstruksi pengetahuan, dan Kesesuaian LAS dengan syarat teknis penyusunan LAS.

5. Lembar Penilaian Autentik: Kesesuaian indikator sikap dengan kompetensi dasar sikap, Kesesuaian diskriptor penilaian sikap dengan indikator sikap, Ketepatan pemberian skor penilaian sikap, Ketepatan klasifikasi penilaian sikap., Kesesuaian indikator soal pengetahuan IPK, Kesesuaian soal dengan indikator soal pengetahuan, Kebenaran kunci jawaban penilaian pengetahuan., Kelayakan penskoran penilaian pengetahuan., Kesesuaian indikator keterampilan dengan kompetensi dasar keterampilan., Kesesuaian diskriptor penilaian keterampilan dengan indikator keterampilan., Ketepatan pemberian skor penilaian keterampilan., dan Ketepatan klasifikasi penilaian keterampilan.

6. Lembar Respon Siswa: Keindahan tampilan LAS, Keserasian komposisi warna dalam LAS, Kejelasan petunjuk kegiatan dalam LAS, Kejelasan ilustrasi dalam LAS, Kejelasan materi dalam LAS, Kekontekstualan materi LAS, Kemudahan siswa memahami materi LAS, Kemanfaatan gambar pada LAS, Menumbuhkan rasa ingin tahu siswa, Menumbuhkan sikap teliti siswa, Menumbuhkan sikap percaya diri siswa, dan Kepuasan siswa menggunakan LAS

Komentar validator terhadap silabus, lembar materi ajar, dan lembar respon siswa adalah baik dengan kategori sangat valid. Sementara untuk Rencana Pelaksanaan Pembelajaran, Lembar Aktivitas Siswa, dan Lembar Penilaian Autentik, dapat dilihat pada Tabel 3, Tabel 4, dan Tabel 5 berikut:

Tabel 3. Rekomendasi Tim Ahli dan Praktisi Pendidikan terhadap RPP

\begin{tabular}{|c|c|c|c|c|c|}
\hline $\begin{array}{c}\text { Perangk } \\
\text { at } \\
\text { Pembela } \\
\text { jaran }\end{array}$ & Komponen & $\begin{array}{l}\text { Aspek } \\
\text { yang } \\
\text { Diper } \\
\text { baiki }\end{array}$ & $\begin{array}{l}\text { Komentar } \\
\text { Validator }\end{array}$ & $\begin{array}{l}\text { Rata- } \\
\text { rata } \\
\text { Skor }\end{array}$ & $\begin{array}{l}\text { Rata- } \\
\text { rata/ } \\
\text { Kate } \\
\text { gori }\end{array}$ \\
\hline \multirow{4}{*}{$\begin{array}{l}\text { Rencana } \\
\text { Pelaksan } \\
\text { aan } \\
\text { Pembela } \\
\text { jaran }\end{array}$} & Identitas RPP & - & Baik & 4 & \multirow{4}{*}{$\begin{array}{c}3,44 / \\
\text { Sangat } \\
\text { Valid }\end{array}$} \\
\hline & $\begin{array}{l}\text { Kesesuaian } \\
\text { Rumusan IPK dan } \\
\text { tujuan } \\
\text { pembelajaran }\end{array}$ & - & Baik & 4 & \\
\hline & $\begin{array}{l}\text { Pemilihan materi } \\
\text { pembelajaran }\end{array}$ & - & Baik & 4 & \\
\hline & $\begin{array}{l}\text { Perumusan } \\
\text { kegiatan } \\
\text { pembelajaran } \\
\text { menggunakan } \\
\text { model PBL dengan }\end{array}$ & $\begin{array}{l}\text { Penera } \\
\text { pan PBL }\end{array}$ & $\begin{array}{l}\text { Beberapa } \\
\text { kegiatan } \\
\text { dalam } \\
\text { langkah } \\
\text { pembelajar }\end{array}$ & 3 & \\
\hline
\end{tabular}




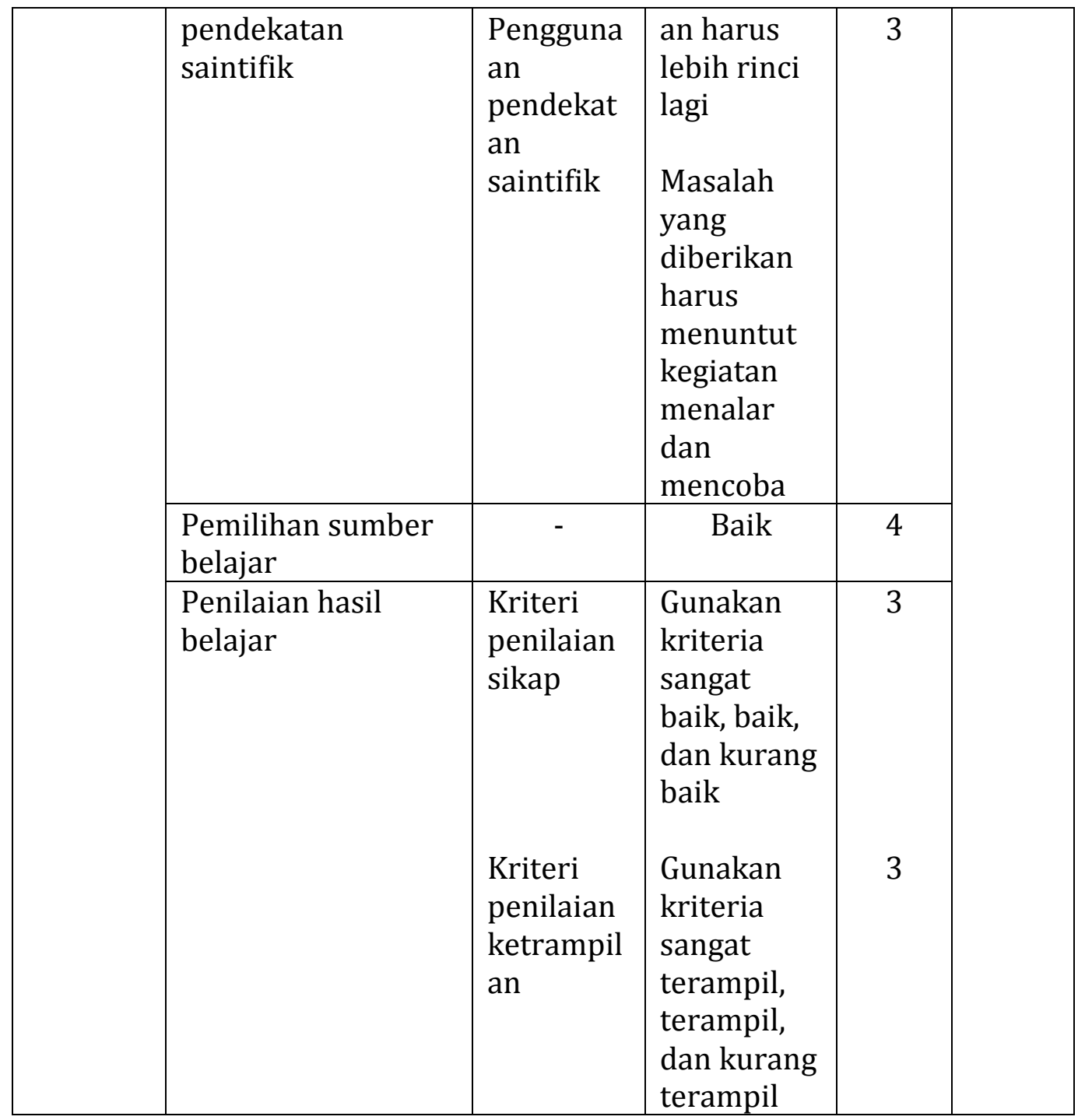

Tabel 4. Rekomendasi Tim Ahli dan Praktisi Pendidikan terhadap LAS

\begin{tabular}{|c|c|c|c|c|c|}
\hline $\begin{array}{l}\text { Perangk } \\
\text { at } \\
\text { Pembela } \\
\text { jaran }\end{array}$ & Komponen & $\begin{array}{l}\text { Aspek } \\
\text { yang } \\
\text { Diper } \\
\text { baiki }\end{array}$ & $\begin{array}{l}\text { Komentar } \\
\text { Validator }\end{array}$ & $\begin{array}{l}\text { Rata- } \\
\text { rata } \\
\text { Skor }\end{array}$ & $\begin{array}{l}\text { Rata- } \\
\text { rata/ } \\
\text { Kate } \\
\text { gori }\end{array}$ \\
\hline \multirow{4}{*}{$\begin{array}{c}\text { Lembar } \\
\text { Aktifitas } \\
\text { Siswa }\end{array}$} & Kualitas materi LAS & - & Baik & 4 & \multirow{4}{*}{$\begin{array}{c}3,67 \\
/ \\
\text { Sang } \\
\text { at } \\
\text { Valid }\end{array}$} \\
\hline & $\begin{array}{l}\text { Kesesuaian LAS } \\
\text { dengan model PBL } \\
\text { dan pendekatan } \\
\text { saintifik }\end{array}$ & $\begin{array}{l}\text { Langkah } \\
\text { penyelidi } \\
\text { dikan }\end{array}$ & $\begin{array}{l}\text { Masalah } \\
\text { dalam Las } \\
\text { lebih } \\
\text { diperjelas } \\
\text { lagi }\end{array}$ & 3,5 & \\
\hline & $\begin{array}{l}\text { Kesesuaian Las } \\
\text { dengan syarat } \\
\text { didaktik }\end{array}$ & - & Baik & 3,5 & \\
\hline & $\begin{array}{l}\text { Kesesuaian LAS } \\
\text { dengan syarat } \\
\text { konstruksi }\end{array}$ & - & Baik & 3,5 & \\
\hline
\end{tabular}

Al-Khwarizmi - 37 


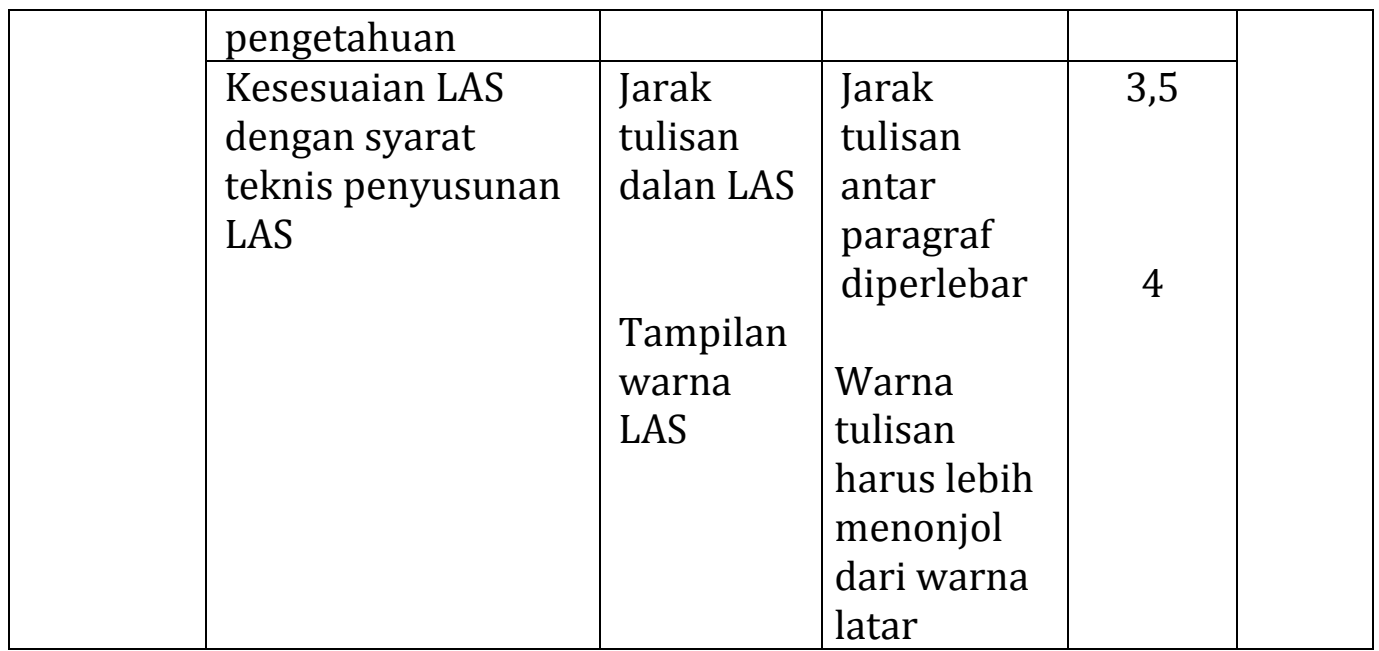

Tabel 5. Rekomendasi Tim Ahli dan Praktisi Pendidikan terhadap LPA

\begin{tabular}{|c|c|c|c|c|c|}
\hline $\begin{array}{c}\text { Perangk } \\
\text { at } \\
\text { Pembela } \\
\text { jaran }\end{array}$ & Komponen & $\begin{array}{c}\text { Aspek yang } \\
\text { Diperbaiki }\end{array}$ & $\begin{array}{l}\text { Komentar } \\
\text { Validator }\end{array}$ & $\begin{array}{c}\text { Rata-rata } \\
\text { Skor }\end{array}$ & $\begin{array}{l}\text { Rata- } \\
\text { rata/ } \\
\text { Kate } \\
\text { gori }\end{array}$ \\
\hline \multirow[t]{7}{*}{$\begin{array}{l}\text { Lembar } \\
\text { Penilaia } \\
\text { n } \\
\text { Autentik }\end{array}$} & $\begin{array}{l}\text { Kesesuaian } \\
\text { indikator sikap } \\
\text { dengan } \\
\text { kompetensi } \\
\text { dasar sikap }\end{array}$ & - & Baik & 4 & \multirow[t]{7}{*}{$\begin{array}{l}3,92 \\
/ \\
\text { Sang } \\
\text { at } \\
\text { Valid }\end{array}$} \\
\hline & $\begin{array}{l}\text { Kesesuaian } \\
\text { diskriptor } \\
\text { penilaian sikap } \\
\text { dengan indikator } \\
\text { sikap }\end{array}$ & - & Baik & 4 & \\
\hline & $\begin{array}{l}\text { Ketepatan } \\
\text { pemberian skor } \\
\text { penilaian sikap }\end{array}$ & - & Baik & 4 & \\
\hline & $\begin{array}{l}\text { Ketepatan } \\
\text { klasifikasi } \\
\text { penilaian sikap. }\end{array}$ & $\begin{array}{l}\text { Kriteri } \\
\text { penilaian } \\
\text { sikap }\end{array}$ & $\begin{array}{l}\text { Gunakan } \\
\text { kriteria } \\
\text { sangat } \\
\text { baik, baik, } \\
\text { dan } \\
\text { kurang } \\
\text { baik }\end{array}$ & 3 & \\
\hline & $\begin{array}{l}\text { Kesesuaian } \\
\text { indikator soal } \\
\text { pengetahuan IPK }\end{array}$ & - & Baik & 4 & \\
\hline & $\begin{array}{l}\text { Kesesuaian soal } \\
\text { dengan indikator } \\
\text { soal } \\
\text { pengetahuan }\end{array}$ & - & Baik & 4 & \\
\hline & Kebenaran kunci & - & Baik & 4 & \\
\hline
\end{tabular}




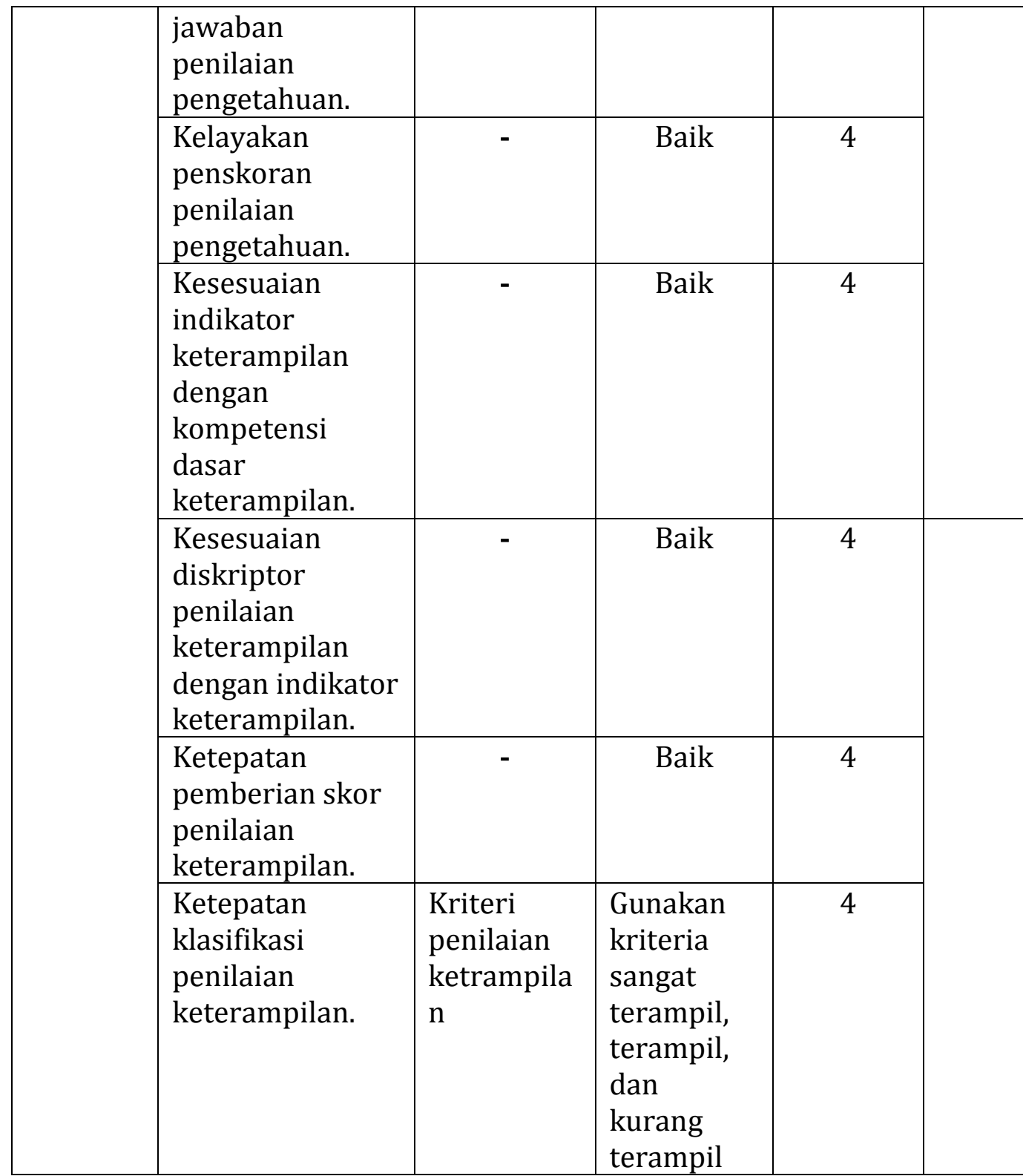

Hasil validasi secara keseluruhan seperti disajikan dalam Tabel 6 berikut: 
Tabel 6. Hasil Validasi Keseluruhan

Perangkat Pembelajaran dan Kepraktisan LAS

\begin{tabular}{|c|l|c|c|}
\hline No. & Perangkat Pembelajaran & Rata-rata & Kategori \\
\hline 1 & Silabus & 3,93 & Sangat valid \\
\hline 2 & $\begin{array}{l}\text { Rencana Pelaksanaan } \\
\text { Pembelajaran }\end{array}$ & 3,44 & Sangat valid \\
\hline 3 & Lembar Aktifitas Siswa & $3,67 / 3,76$ & $\begin{array}{l}\text { Sangat valid / } \\
\text { sangat praktis }\end{array}$ \\
\hline 4 & Lembar Materi Ajar & 3,83 & Sangat valid \\
\hline 5 & $\begin{array}{l}\text { Lembar Penilaian } \\
\text { Autentik }\end{array}$ & 3,92 & Sangat valid \\
\hline 6 & $\begin{array}{l}\text { Respon Siswa Terhadap } \\
\text { LAS }\end{array}$ & 3,75 & Sangat Praktis \\
\hline
\end{tabular}

Perangkat pembelajaran yang telah divalidasi oleh validator dan praktisi pendidikan serta dari respon siswa telah dilakukan revisi sesuai komentar dan saran yang diberikan. Dari Tabel 6 disimpulkan bahwa perangkat yang dikembangkan telah memenuhi aspek kevalidan dan perangkat layak diujicobakan kepada siswa SMP/MTs pada skala yang lebih luas. Dari hasil respon siswa disimpulkan bahwa LAS sudah praktis untuk digunakan dalam pembelajaran materi pecahan dan himpunan.

\section{Penutup}

Dari pengembangan perangkat pembelajaran yang telah dilaksanakan diperoleh kesimpulan bahwa perangkat yang dikembangkan telah direvisi sesuai dengan saran validator dan praktisi sehingga perangkat siap untuk diujicobakan kepada siswa SMP/MTs pada skala yang lebih luas.

\section{Daftar Pustaka}

Amir, Muhammad Taufiq. Inovasi Pendidikan Melalui Problem Based Learning: Bagaimana Pendidik Memberdayakan Pebelajar Di Era Pengetahuan. Jakarta: Kencana Prenada Media Group, 2009.

Arsyad, Azhar. Media Pembelajaran. Jakarta: Raja Grafindo Persada, 2007. Depdiknas. Panduan Pengembangan Bahan Ajar. Jakarta: Depdiknas, 2008. Dwicahyono, Aris. Pengembangan Perangkat Pembelajaran. Yogyakarta: Gava Media, 2014.

Kunandar. Penilaian Autentik (Penilaian Hasil Belajar Peserta Didik Berdasarkan Kurikum 2013). Jakarta: PT Raja Grafindo Persada, 2014.

Madeamin, Ishaq. 'Objektivitas Dan Kepraktisan', 2011. http://shahibul1628.wordpress.com/2012/04/12/kepraktisan-danefek-potensial/.

Nazaruddin. Manajemen Pembelajaran. Yogyakarta: Teras, 2007.

Prastowo, Andi. Panduan Kreatif Membuat Bahan Ajar Inovatif. Yogyakarta: Duva Press, 2011. 
Pengembangan Perangkat Pembelajaran Matematika ...

Rusman. Model-Model Pembelajaran Mengembangkan Profesionalisme Guru. Jakarta: Rajawali Press, 2012.

Sudjono, Anas. Pengantar Statistik Pendidikan. Jakarta: Rajawali Press, 2009.

Sugiyono. Metode Penelitian Pendidikan Pendekatan Kuantitatif, Kualitatif, Dan $R \& D$. Bandung: Alfabeta, 2013.

Suherman. Strategi Pembelajaran Matematika Kontemporer. Surabaya: JICA, 2001.

Trianto. Mendesain Model Pembelajaran Inovatif-Progresif. Jakarta: Kencana Prenada Media Group, 2009.

-_- Model-Model Pembelajaran Inovatif Berorientasi Konstruktivis. Jakarta: Prestasi Pustaka Publisher, 2007.

Widoyoko, Eko Putro. Kamus Besar Bahasa Indonesia. 4th ed. Jakarta: PT. Gramedia Pustaka Utama, 2008. 
Armis \& Suhermi

Halaman ini sengaja dikosongkan

Al-Khwarizmi - 42 